\title{
NMES
}

New Middle Eastern Studies

ISSN: 2051-0861

Publication details, including guidelines for submissions:

https://journals.le.ac.uk/ojs1/index.php/nmes

\section{Reconsidering the Palestine Issue in the Shade of Israel's Expanding Sovereignty Claim}

Author(s): M. Hüseyin Mercan

To cite this article: Mercan, M. Hüseyin (2018) "Reconsidering the Palestine Issue in the Shade of Israel's Expanding Sovereignty Claim", New Middle Eastern Studies 8 (2), pp. 6883.

Online Publication Date: 19 January 2019

\section{Disclaimer and Copyright}

The NMES editors make every effort to ensure the accuracy of all the information contained in the journal. However, the Editors and the University of Leicester make no representations or warranties whatsoever as to the accuracy, completeness or suitability for any purpose of the content and disclaim all such representations and warranties whether express or implied to the maximum extent permitted by law. Any views expressed in this publication are the views of the authors and not the views of the Editors or the University of Leicester.

Copyright New Middle Eastern Studies, 2019. All rights reserved. No part of this publication may be reproduced, stored, transmitted or disseminated, in any form, or by any means, without prior written permission from New Middle Eastern Studies, to whom all requests to reproduce copyright material should be directed, in writing.

\section{Terms and Conditions}

This article may be used for research, teaching and private study purposes. Any substantial or systematic reproduction, re-distribution, re-selling, loan or sub-licensing, systematic supply or distribution in any form to anyone is expressly forbidden.

The publisher does not give any warranty express or implied or make any representation that the contents will be complete or accurate or up to date. The accuracy of any instructions, formulae and drug doses should be independently verified with primary sources. The publisher shall not be liable for any loss, actions, claims, proceedings, demand or costs or damages whatsoever or howsoever caused arising directly or indirectly in connection with or arising out of the use of this material. 


\title{
Reconsidering the Palestine Issue in the Shade of Israel's Expanding Sovereignty Claim
}

\author{
M. Hüseyin Mercan*
}

\begin{abstract}
The Palestine question is among the most important and longstanding conflicts in the world. A lasting solution could not be found and problems have multiplied after the foundation of the State of Israel in 1948, mainly because the sovereignty of the Palestinian people has been disregarded. Though the conflict includes complex issues such as the legal status of Jerusalem, the refugees' right to return to their ancestral lands and the rapid increase in Jewish settlements; the root of the problem is the lack of an equal sovereign rights approach for both sides. The Palestine issue has been rendered more and more tragic over the years as Israel does not permit the Palestine Authority to exercise its sovereign rights in its own lands and the international community refrains from imposing sanctions on Israel despite its continuous violations of international law and UN (United Nations) resolutions. Especially as a result of Israel's recent policies towards expanding its sovereignty claims over the entire Palestinian territory, an even darker period seems to cloud Palestine's sovereignty in the near future. This study claims that the source of the longstanding Israel-Palestine conflict is the inequality in exercising sovereign rights between the two parties and discusses how Israel's expansionist activities may shape the Palestine issue in the forthcoming years. Furthermore, the study scrutinizes how the "Jewish Nation State Basic Law" - that was recently approved by the Israeli parliament - will sabotage the ongoing search for peaceful solutions and it may destroy all hopes for establishing a lasting peace between the two peoples in the foreseeable future.
\end{abstract}

Keywords: Sovereignty; Palestine; Israel; Jewish Nation State Basic Law; Palestine Issue

\section{Introduction}

The Palestine issue is one of the most important and longstanding conflicts in the global order of nation-states that came into existence after World War I. The demographic situation within the former British Mandate of Palestine changed dramatically after Jewish settlements massively increased in numbers throughout the 1930s and 1940s, generating a new status quo. With the declaration of Israel's independence in 1948, the Palestine issue further intensified and it continues to this day. As the State of Israel claims absolute sovereignty over the entire Mandate of Palestine territories, the sovereignty issue remains at the heart of the ongoing Palestinian-Israeli dispute.

\footnotetext{
*M. Hüseyin Mercan; Assistant Professor, Department of International Relations, Ankara Yıldırım Beyazıt University, Ankara, Turkey. Email: mercanmh@yahoo.com.
} 
Considering that the sovereignty of states is fundamental to the functioning of modern international relations, it is hardly surprising that the struggle for equal sovereignty is also the basis of the Israeli-Palestinian dispute. Sovereignty is the most important dimension of the modern state, both within the borders of its authority and its relations with other actors of global politics. The expansionist policy of the State of Israel in the Palestinian territories since 1948 is a strategy that obviously disregards the Palestine people's sovereign rights over the same lands. For decades, all attempts of peace and reconciliation on the issue under the observation of UN (United Nations) and/or other international organizations have repeatedly failed. The main reason behind this ongoing failure is that the sovereignty rights of the Palestinian people have not received equal recognition by Israel.

The State of Israel which secured the status of its own nation-state in the late 1940s, exploits the juridical rights of the situation, manipulates the international society and denies Palestinians their rights to self-determination and to establish sovereignty. With the support of the United States (US) and the silence of the majority of international community in the face of the unlawful activities of the State of Israel, its sovereignty in the lands of Palestine has expanded. The situation has escalated into an even more dangerous level throughout 2018. As the US President Donald Trump decided to relocate the embassy of the United States from Tel Aviv to Jerusalem and implemented the decision, the liberation struggle of Palestinians has become even more difficult than before. With the recognition of Jerusalem as Israel's capital by the principal actor of global politics, the US, the possibility of an independent sovereign state of Palestine has been minimalized. The nation state bill that was passed by the parliament of Israel, the Knesset, with the support of the United States, serves to expand Israel's sovereignty claims and limits the territory and the political rights of Palestinians.

This article addresses the Palestine issue through Israel's expanded sovereignty policy and argues that the Israeli-Palestinian dispute is ultimately a matter of struggle for sovereignty. Without an equal and just sovereignty mentality between the two sides, it is not possible to find a peaceful solution and to establish political stability in the region. In the article, by referring to the arguments on sovereignty and sovereign states in the international relations (IR) discipline, it is emphasized that the sovereignty of Palestine is as "just" and "holy" as that of other nation-states and it is made clear that none of the proposals given by international organisations or intermediary states have so far been realistic, as they have not taken into account the integral sovereignty of Palestinian people themselves in their ancestral lands. Moreover, this article suggests that the recent declaration of the so-called "Jewish nation-state law" should be discussed within the framework of Israel's established strategy of sovereignty expansion and that the quest of international community for resolution in relation to Palestine cannot be conceivable unless Israel relinquishes its absolute sovereignty claims over Palestine's territory.

\section{Sovereignty as the Source of the Palestinian-Israeli Dispute}

The Treaty of Westphalia of 1648 is considered to be the beginning of modern international relations. The reason why this treaty has become one of the turning points of history is the fact that it established a new definition of state and sovereignty. An understating of "a 
definite and absolute authority" (Hinsley 1986: 26) is meant as a transition from a divine authority, or in other words, the continental authority of the Catholic Church, to another political structure controlled by nations with fixed boundaries. The Treaty of Westphalia considers the state as the "supreme and sovereign power" in its own territory and the Church is detached from political authority (Zacher 1992: 59). Therefore, the transnational sovereignty of the Church - that was being implemented for centuries - passed onto the hands of a state that is based on territorial integrity and the process has also placed the idea of nation as its core foundation. According to Hans Morgenthau, the Treaty of Westphalia, while instituting the basis of international law, ended the religion-based disputes and established the "territorial state as the cornerstone of the modern state system" (Morgenthau 1993: 254).

The aforementioned perspective of modern international relations, unlike the traditional political systems, can be interpreted only on a nation-state basis. The most important characteristic of the nation-state is that it includes sovereignty entirely in itself. Given the fact that F. H. Hinsley argues that one cannot mention sovereignty in stateless societies, it could be stated that modern nation states can be defined as sovereign-states within fixed boundaries (Hinsley 1986: 22). Therefore, the primary characteristic of modern states is that they own the monopoly of sovereignty (Yurdusev 2006: 20). The perspective that there would be no sovereignty establishment and the international politics of entirely independent countries would be declared null and void reveals the fact that the existence of modern international system can be explained only by referring to sovereignty (Reus-Smit 2014: 275).

Even though the right of sovereignty is used by the state, it should be noted that the domain of sovereignty must be understood in two distinct areas - which are the interior of the borders and the context of international relations. The sovereignty of the state or its right of implementing its sovereignty is related to the fact that it is the supreme authority within its borders, however, in the context of international relations it is directly related to the recognition of and by other states (Lake 2003: 305). Sovereignty - as defined by Carl Schmitt as the right to declare a "state of emergency" (Schmitt 2010: 13) and as "the monopoly of legitimate force" by Max Weber (2008: 156) - means that a state has a relatively large space of manoeuvre within its borders. Stephen D. Krasher defines this type of sovereignty which he calls the domestic sovereignty as follows: "Domestic sovereignty refers to the formal organization of political authority within the state and the ability of public authorities to exercise effective control within the borders of their own polity" (Krasner 1999: 4).

Although the interior of borders is an area of freedom for a sovereign state, it does not mean that the state can do anything it wants and it is immune from the influence of those actors around it. Within this scope, Kenneth Waltz focuses on the decision making process of the state, rather than a political structure which is free from all type of influence when he defines the sovereign state. According to him, the sovereign state is the structure which decides how it will handle its internal and external issues or if it will request foreign assistance for these issues, determines its own strategy and chooses which areas to develop or experience. Therefore, sovereignty expands the area of manoeuvre of the state whereas at the same time, limits the state given its position in the international politics and the conditions to which it is subject (Waltz 1979: 96). This is caused by the complex dimensions of sovereignty. One cannot think of sovereignty without the modern state structure in 
international relations. In addition to this, recognition, authority and coercion are other important dimensions of sovereignty (Thomson 1995: 219-228). "Authority" and "coercion" imply the domestic sovereignty of a state whereas "recognition" is related to the existence of state in the international system and being a legitimate actor in the international relations.

Even though the right of sovereignty is meant to be used equally among all states in accordance with juridical norms, the fact that international relations are dominated by the realistic understanding of power puts weaker states in a difficult position against powerful states. Edward H. Carr defines international politics as a "politics of power" with the emphasis on its indispensable side as an administrative tool. From this point of view, Carr specifies the international administration as the administration by the states powerful enough to realise it and signifies that the current international system is power-based (Carr 2001: 97, 101). Internationalization of power and re-establishment of a world order through this process grants significant privileges to superior powers and highlights the potential inability of certain weaker powers to implement their own rights of sovereignty. According to this perspective, the Israeli-Palestinian dispute could be analysed in the context of two polities with vastly differing levels of power, capabilities to manoeuvre and capacities in the international system, thus it could be understood that the status quo is fairly disadvantageous for Palestine.

The disregard for ethical norms and the prioritisation of powerful nations' interests in modern international relations prevents the discussion of sovereignty within a fair and just context. Even though the pluralists define sovereignty as an ethical principle where different states and cultures coexist, in the current world order, it is clear that ethical norms are not the determining factors. Indifference to the pain of others and a power/interest based world order undermines the understanding of sovereignty and causes injustices in international order (Aral 2016: 62). Particularly on this matter, it should be noted that the reason behind the lack of solution for the Palestine issue is the fact that the interests of the powerful are emphasized in international politics, rather than what is ideally ethical. The fundamental problem is that during the status quo that was shaped after World War I, the process of state formation between the Jewish settlers and the rightful inhabitants of the Palestine region was not justly handled. One of the two communities, that had similar status at the beginning, gradually acquired relatively high levels of privileges and founded a new state, whereas the other one was consistently forced to leave what it had, and the Palestinian people was counselled that the peaceful solution was to recognize the absolute sovereignty of the newly-founded State of Israel on their ancestral lands.

The principal reason behind the lack of solution between the two sides is the absence of a balance of power during the negotiations. Even though it is a relatively small-sized nation state, the State of Israel possesses a power capacity that far exceeds the territories it controls and therefore it has succeeded to manipulate the international society and impose psychological pressure on the Palestinians (Davutoğlu 2003: 5). In light of such a bitter situation, the State of Palestine has a limited space of manoeuvre and thus, is unable to even voice its perspective during negotiation periods. The fact that the State of Israel claims to be independent of - or superior to - the norms of the international system is disregarded, whereas the struggle of the Palestinian side is being interpreted in different contexts. While the State of Israel utilizes its capacity of diplomacy and power that is beyond a regular nation state's limits, the State of Palestine is unable to implement its right of sovereignty. 
Consequently, the State of Israel is more and more perceived as an entity superior to a nationstate, whereas the image of the State of Palestine as an inferior nation-state, incompetent even in controlling its own borders (i.e. the West Bank and Gaza) is being imposed (Davutoğlu 2003: 5-6).

The negligence of capabilities provided by international law has deprived the Palestinian side of the effective use of its right of sovereignty and/or its right of selfdetermination. This situation is a direct result of the prioritization of the State of Israel's interests by powerful global actors such as the US and the durability of the status quo that is imposed in the region by the global order. The aim behind the unjust treatment of societies that are considered to be the "others" of the existing world order is to protect the West-centric balance of power and Western global hegemony. Within an order where the states prioritize maximising their interests, it is futile to prioritize ethical norms and values. In this context, the international relations order which has a sovereignty concept that is formed by power and interests "focuses on which is de facto rather than which is de jure and minimizing the change of the current balance of powers and to guarantee it" (Aral 2016: 119-120). The cause of the Israeli-Palestinian dispute being evaluated according to the interests of the powerful side rather than a mutually beneficial and just negotiation perspective is, in a way, compatible with the founding and determining principles of the current international relations. The possibility of establishing a peaceful resolution process that is both just and equal to both sides and the full recognition of Palestine's right of sovereign - as equal to that of the State of Israel - would shake the current balance of powers and interests that have been determining the fate of the region for a long time since the end of World War I. This is why the supporters of the State of Israel disregard juridical and ethical norms and marginalise the side of Palestine while struggling for an Israel-centred resolution.

\section{The Bias of the Solution Process and the Solitude of Palestine}

Following the establishment of the State of Israel, the dispute between two stateless communities became an institutional one and with the international disregard of the Palestinian people, a realistic solution became even harder to realise. Britain largely supported the establishment of the State of Israel during its 1918-1948 mandate rule through interruptions of Palestinians' attempts to form their national integrity, sympathising with the aggressive territorial expansionism of Zionists and the disregard it showed to Palestinians' demands (Khalidi 2006: 182-183). This situation inevitably turned into a strategy of a state expanding its sovereignty unto a stateless community. Especially after the 1967 War, Israel's sovereignty claims on the lands it occupied played a substantial role in intensifying the problem.

Expanded territories and increasing demands of sovereignty of the State of Israel brought new dimensions to the dispute which had been going on through the settlements and refugees. The legal status of Jerusalem, the establishment of an independent and sovereign State of Palestine and the distribution of economical and natural resources are other principal topics of dispute between the two sides. Without a doubt, the inability of international society to adequately respond to and the decisions taken that are far from being sanctions have 
encouraged the State of Israel to continue its expansionist agenda of sovereignty and the situation benefited the State of Israel. After the wars of 1967 and 1973, the fact that the State of Israel did not act in accordance with the United Nations Security Council's (UNSC) decisions, turned the Palestinian issue to a dispute where the great powers overlook one side's actions while impeding those of the other.

The United Nations Security Council Resolution 242 of 22 November 1967 clearly states that territories on which the State of Israel claims sovereignty are in fact occupied and it is emphasized that the armed forces of Israel should be retreated immediately and the rights of sovereignty of both sides should be respected:

The Security Council...

1. Affirms that the fulfilment of Charter principles requires the establishment of a just and lasting peace in the Middle East which should include the application of both the following principles:

(i) Withdrawal of Israel armed forces from territories occupied in the recent dispute;

(ii) Termination of all claims or states of belligerency and respect for and acknowledgment of the sovereignty, territorial integrity and political independence of every State in the area and their right to live in peace within secure and recognized boundaries free from threats or acts of force;

2. Affirms further the necessity

(a) For guaranteeing freedom of navigation through international waterways in the area;

(b) For achieving a just settlement of the refugee problem;

(c) For guaranteeing the territorial inviolability and political independence of every State in the area, through measures including the establishment of demilitarized zones (Security Council Resolution of 242, 1967).

Even though the points mentioned in the above document deemed the State of Israel as an occupier and secured the rights of Palestinians as much as possible, the fact that the State of Israel disregarded the Resolution clearly shows that the Resolution has not been consequential. The UNSC's Resolution 338 following the 1973 War called upon ceasefire and the implementation of the Resolution 242, yet it has not lead to any real gains either. The lack of an attempt to recognise Palestine's right of sovereignty has hindered the establishment of peace and has undermined the trust built on both the United Nations and the international law.

As a result of the support of great powers, mainly the US, and the incapacity of Palestine, the State of Israel has constantly expanded its claims of sovereignty. The basic law entitled Jerusalem, which was passed by Knesset on 30 July 1980, added a new dimension to the sovereignty-centred dispute. Considering that the State of Israel has no constitution and the structure and operation of the state is determined by basic laws, one could argue that this law has constitutional certainty and validity. The line which states that "the complete and united Jerusalem is the capital of Israel" (Basic Law: Jerusalem the Capital of Israel, 1980) claims Jerusalem within Israel's absolute sovereignty while also disregarding both Palestine's sovereignty and all of the international decisions and procedures regarding the special status of Jerusalem.

It was clearly stated by the British Mandate that the historical region including the holy sites within Jerusalem are subject to the ownership of Muslims, in other words, the Palestinians living in the area. The commission published a resolution on 8 June 1931: 
To the Moslems belong the sole ownership of, and the sole proprietary right to, the Western Wall, seeing that it forms an integral part of the Haram al-Sharif area, which is a Waqf property.

To the Moslems there also belongs the ownership of the pavement in front of the Wall and of the adjacent so-called Moghrabi (Moroccan) Quarter opposite the Wall, inasmuch as the last-mentioned property was made Waqf under Moslem Sharia law, it being dedicated to charitable purposes.

Such appurtenances of worship and/or such other objects as the Jews may be entitled to place near the Wall either in conformity with the provisions of this present verdict or by agreement come to between the Parties shall under no circumstances be considered as, or have the effect of, establishing for them any sort of proprietary right to the Wall or to the adjacent Pavement...

The Jews shall have free access to the Western Wall for the purpose of devotions at all times... (United Nations 1997).

As it is stated on the report of the commission, given the historical and juridical data, there is no legitimacy to the sovereignty claims of Israel on the entirety of Jerusalem. In addition, the State of Israel adding the territory to its municipal boundaries after the attack of July 1967 on East Jerusalem is a significant step towards changing the legal status of Jerusalem. The United Nations General Assembly, which formed immediately after this incident on the 4th of July, declared the invalidity of the attack of the State of Israel and the attempt to change the status of Jerusalem with Resolution 2253. General Assembly calls to action with these issues:

The General Assembly,

Deeply concerned at the situation prevailing in Jerusalem as a result of the measures taken by Israel to change the status of the City,

1. Considers that these measures are invalid;

2. Calls upon to rescind all measures already taken and to desist forthwith from taking any action which would alter the status of Jerusalem;

3. Requests the Secretary-General to report to the General Assembly and the Security Council on the situation and on the implementation of the present resolution not later than one week from its adoption (UN General Assembly Decision of 2253, 1967).

As a result of Israel's lack of action in the face of the General Assembly's resolutions, the Security Council put forward a resolution on 21 May 1968 directly concerning the status of Jerusalem. The Council aimed to discourage the State of Israel and called it to act according to the principles stated in the following resolution:

1. Deplores the failure of Israel to comply with the General Assembly resolutions mentioned above;

2. Considers that all legislative and administrative measures and actions taken by Israel, including expropriation of land and properties thereon, which tend to change the legal status of Jerusalem are invalid and cannot change the status;

3. Urgently calls upon Israel to rescind all such measures already taken and to desist forthwith from taking any further action which tends to change the status of Jerusalem (Security Council Resolution of 252, S/RES/252, 1968).

As a consequence of the State of Israel standing its ground and continuing its claims of sovereignty over Jerusalem, the General Assembly and the Security Council continued to 
issue resolutions. As mentioned before, the Jerusalem Basic Law aiming to reinforce the right of sovereignty on Jerusalem, which is passed by Knesset, resulted in a strict resolution by UNSC. On 20 August 1980, Resolution 478 the Security Council expressed its concerns on the law that is passed by Knesset as follows: “...Deeply concerned over the enactment of a 'basic law' in the Israeli Knesset proclaiming a change in the character and status of the Holy City of Jerusalem, with its implications for peace and security...". In addition, the points regarding the status of Jerusalem and the invalidity of the demand of sovereignty made by the State of Israel are also important to note:

1. Censures in the strongest terms the enactment by Israel of the "basic law" on Jerusalem and the refusal to comply with relevant Security Council resolutions;

2. Affirms that the enactment of the "basic law" by Israel constitutes a violation of international law and does not affect the continued application of the Geneva Convention relative to the Protection of Civilian Persons in Time of War, of 12 August 1949, in the Palestinian and other Arab territories occupied since June 1967, including Jerusalem;

3. Actions taken by Israel, the occupying Power, which have altered or purport to alter the character and status of the Holy City of Jerusalem, and in particular the recent "basic law" on Jerusalem, are null and void and must be rescinded forthwith;

4. Affirms also that this action constitutes a serious obstruction to achieving a comprehensive, just and lasting peace in the Middle East;

5. Decides not to recognize the "basic law" and such other actions by Israel that, as a result of this law, seek to alter the character and status of Jerusalem and calls upon:

6.

a) All Member States to accept this decision;

b) Those States that have established diplomatic missions at Jerusalem to withdraw such missions from the Holy City (Security Council Resolution of 478, S/RES/478, 1980).

The most important characteristic of the UN Security Council Resolution 478 is that, for the first time, there has been a formal international request to ensure Israel's sovereignty claim over Jerusalem to be declared null and void. The states that had diplomatic relations with Israel had decided to withdraw their embassies and this was an important step aiming to protect the status of Jerusalem. However, Israel's reluctance to act in accordance with the aforementioned resolutions and many of the great powers including the Security Council members acknowledging Israel's de facto sovereignty over Jerusalem and other parts of Palestine have made it extremely difficult to establish a permanent solution.

The State of Israel acting in spite of the United Nations Resolutions was followed by the peace negotiations between Palestine and Israel, mainly with the initiative of the US. Many attempts during the 1990s such as the Madrid, Oslo, Washington and Camp David initiatives sought a peaceful resolution to the situation. Yet, the Israel-focused approach during these negotiations caused the negotiations to fail to reach the desired ends and led to further disregard the sovereignty right of Palestine. The Oslo Accords, which was signed in Washington in 1993 after the Madrid Conference of 1991, was an important step to achieve peace between two sides. With this agreement, the armed forces of Israel occupying Gaza and Jericho were anticipated to retreat and a new transitory administration was envisaged (Declaration of Principles on Interim Self-Government Arrangements (Oslo Accords), 1993). On the other hand, the fact that there were no sanctions for the State of Israel if it decided to violate the agreement, the borders of Palestine being limited to only West Bank and Gaza, 
and the situation of Jerusalem being postponed only served to invalidate the agreement. Ultimately, Israel acted leisurely regarding the issue of military withdrawal and continued the construction of new settlements in Jerusalem and West Bank. Therefore it can be argued that this agreement "projected an ambiguous autonomy which would harm the right to selfdetermination of Palestinian people rather than independence" (Aral 2016: 151). Also, according to this agreement, the Palestine Authority's structure, its responsibilities, and very important political matters such as elections were contingent on the approval of the Zionist state. Therefore, the said agreement amounted to a total neglect of Palestine's sovereignty and many of the above conditions were clearly very offensive for Palestinians (Achcar 2004: 273).

The former US Under-Secretary of State, George. W. Ball, argues in an article he published in 1977 that the only way to solve the Israeli-Palestinian dispute is for the Arab states to recognize the sovereignty of Israel and the Israeli armed forces being withdrawn to territories before the War of 1967 (Ball 1977: 460). As a foreign affairs staff member who knew the position of the US very well, his proposal which centred upon the reciprocal recognition of both side's sovereignties was especially noteworthy. Yet, the US-led peace negotiations from the 1990s and the US reluctance to apply any pressure on the administration of Israel on the issue of retreating to its pre-1967 borders prove that the process continues as Israel has desired.

During the peace negotiations between Israel and Palestine, Israel's position has always been to put forward its interests and to guarantee its sovereignty. Ahmet Davutoğlu summarizes the parameters of Israel's position as such:

1. Palestine needs to become a demilitarized state;

2. Palestine must be prohibited from signing military treaties with other states;

3. Israel needs to have the right of flying in the air space of Palestine and during emergency situations, utilize its armed forces through West Bank to Jordan Rift Valley if needed;

4. Sovereignty of Israel on territories occupied by the Jewish settlers in West Bank and Gaza should be established, which means the control of the most strategic locations in practice;

5. In order to create a "control matrix" and ensure West Bank is connected to Israel at an ultimate level, which would make Palestine financially depended on Israel, right to control should be preserved only on the slip roads for the Jews in the settlements (Davutoğlu 2003: 34).

The parameters summarized by Davutoğlu are aimed to make Palestine completely dependent on Israel and disregard its sovereignty altogether. The idea of a demilitarized Palestine only serves to show how much the peace negotiations have been one-sided so far. These attempts to disregard Palestinian sovereignty and intervene in its domestic authority has naturally alienated Palestine and prevented a healthy and durable peace from being established during the negotiations. Even though the United Nations, in the Declaration on Principles of International Law concerning Friendly Relations and Co-operation among States, prohibited a state from intervening in the internal affairs of another state, the interventions of the State of Israel over the domain of Palestine have been ignored. In the resolution, it is said that: 
No State may use or encourage the use of economic political or any other type of measures to coerce another State in order to obtain from it the subordination of the exercise of its sovereign rights and to secure from it advantages of any kind. Also, no State shall organize, assist, foment, finance, incite or tolerate subversive, terrorist or armed activities directed towards the violent overthrow of the regime of another State, or interfere in civil strife in another State (Declaration on Principles of International Law concerning Friendly Relations and Co-operation among States in accordance with the Charter of the United Nations - UN Documents: Gathering a body of global agreements, 1970).

Even though in terms of international law, Israel's intervention into Palestine is entirely prohibited, the illicit activities of Israel prevent the establishment of a legitimate authority in Palestine. Against all juridical texts and practices, Israel constantly intervenes into domestic Palestinian affairs and attempts to justify its absolute sovereignty over the entire former Mandate of Palestine. The Israeli refusal to recognise the victory of Hamas in the Palestinian legislative elections in 2006 is directly related to the sovereignty of Palestine. The election results shocked everyone who was interested in the Israeli-Palestinian dispute, and caused many of the actors including the State of Israel and the US to sabotage the legitimate victory of Hamas. While the victory of Hamas - which is being consistently accused of being a "terrorist organisation" by Israeli and American sides - has been disregarded, a stalemate over the Palestine issue has become unavoidable. ${ }^{1}$ Thus; Hamas entered a difficult period of ceaseless Israeli attacks and pressure under the heavy blockade on the Gaza Strip.

Persistence of Israel on its aggressive attitude and its military operations on territories that are subject to the Palestinian Authority aim only to end the struggle of Palestine for political existence and establish sovereignty on all Palestinian regions. Therefore, it could be said that the State of Israel violates "one of the most fundamental principles of international law that necessitates the states acting according to the agreements which is the pacta sunt servanda" (Aral 2016: 152). The State of Israel - which is immune to sanctions - only receives condemnations from the United Nations and aims to expand its demands of sovereignty and on the other hand end the struggle for the existence of Palestine.

\section{The Jewish Nation State Law and Israel's Expanding Sovereignty Claim}

On 19 July 2018, the Knesset approved a basic law that will radically change the attitudes regarding the Palestine issue and reinforce the sovereignty claim of Israel. The nation state law that was approved by 62 votes against 55 (Lis \& Landau 2018) is important in the sense that it expands the territory on which Israel claims sovereignty. With the new law, Israel puts its settlement and expansion policies, which are not legitimate according to international law and humanitarian values, in practice with the absolute sovereignty of a nation-state. Without a doubt, this situation empowers the State of Israel in the international domain whereas it also deepens the Palestine issue and accelerates its evolution towards a political deadlock.

Considering the fact that there were no equal grounds for negotiations and Palestine's internal and external sovereignty were not recognized from the beginning and therefore the problem never achieved a resolution, the territory demanded for sovereignty by Israel being expanded would be an obstacle for Palestine's demands for independence and sovereignty. 
From its establishment, the State of Israel claimed to be the homeland of all Jewish people; however this statement did not have a constitutional certitude. With the new law being approved, the situation escalated into a juridical status and Israel is now defined as the exclusive national homeland of Jewish people. The first article of the law that provides the right to self-determination exclusively to the Jewish people is as follows:

(a) The Land of Israel is the historical homeland of the Jewish people, in which the State of Israel was established.

(b) The State of Israel is the nation state of the Jewish People, in which it realizes its natural, cultural, religious and historical right to self-determination.

(c) The exercise of the right to national self-determination in the State of Israel is unique to the Jewish People (Basic Law: Israel - The Nation State of the Jewish People, n.d.).

It is clear that the State of Israel aims to repress any potential demands for independence or autonomy from its non-Jewish subjects. Moreover, the borders being defined as the historical homeland of the Jewish people officially transform non-Jewish Israeli citizens as the marginalised "others" in the eyes of the state. Thus, Israel, redefining the citizenship which is the principal parameters of nation-states, disregards the juridical and humanitarian norms by establishing ethno-religious stratification among its citizens. This article has implications for the political entity and sovereignty of Palestine as well. Considering the fact that Jewish settlers are increasing consistently in numbers, mainly in areas that belong to the Palestinians, especially in the east of Jerusalem, the demands of self-determination of non-Jewish people will not be accepted as legitimate and therefore, the State of Israel will utilize its right of sovereignty to use force. In other words, this situation renders the demands of independence of Palestinians as illegitimate within the laws of the State of Israel. The seventh article of the law in particular gives hints on this matter: "The State views the development of Jewish settlement as a national value, and shall act to encourage and promote its establishment and strengthening." The political system that considers the construction of new settlements as a national value is obviously far from a mentality that seeks a permanent peaceful resolution to the problem.

Similar to the Jerusalem Basic Law of 1980, the fact that Jerusalem is mentioned as the "complete and united" capital of Israel is repeated in the third article of the nation state law. Compared to the 1980 status quo, it could be said that in the article that aims to declare the Jewish nation state, the emphasis on Jerusalem with an understanding of absolute sovereignty demonstrates that resolutions including two states or the rights of Palestinians on Jerusalem are completely disregarded. In the current situation, the State of Israel which uses its rights of sovereignty on the entirety of Jerusalem will not allow an East Jerusalem-based Palestine State or any representatives of any other state in the Palestinian region on East Jerusalem. The US decision to re-locate its Israeli embassy to Jerusalem encouraged the Knesset to pass this basic law which is essentially a unilateral declaration of absolute sovereignty on the entire Palestinian territory. Therefore, due to its contents and possible consequences, this law would radically affect the future of Palestine issue and complete the ongoing de facto Israeli penetrations into the Palestinian lands.

The Prime Minister Benjamin Netanyahu's statement after the passing of the Basic Law is the most important evidence which shows that the law is not a decision taken by a 
democratic State of Israel, but rather a notable step to turn the non-Jewish citizens into second-class citizens - the "others" - and to expand the Israeli occupation over entire Palestinian territory. Netanyahu has admitted that the background of the law is based upon the Zionist thought and objectives by defining the accepted law as "a pivotal moment in the annals of Zionism and the State of Israel" (Staff, n.d.). Considering that one of the fundamental reasons for the lack of a solution in the Palestine issue is the uncompromising political aspirations of the Zionist ideology, it becomes evident that the Netanyahu administration endeavours to create an expanded State of Israel that neither recognises a state of Palestine nor the political existence of any Palestinians.

The statements of Israeli authorities which were made after the passing of the law and announced the construction of new settlements are examples for Israel's expanding sovereignty claim over Palestinian territories. Particularly, the Israeli administration's announcement of the construction of 20.000 new houses for Jewish settlers in East Jerusalem in mid-August (Israeli Authorities Approve 20,000 New Settlement Units in JerusalemIMEMC News 2018) shows that Israel takes decisions and implement them even in East Jerusalem as if it is under Israeli sovereignty, despite clearly violating international law and numerous UN resolutions. Furthermore, Israel's 22 August announcement of the construction of 1.000 new houses in the West Bank region is the primary evidence that suggests that the occupation over Palestinian lands is attempted to be based upon a legal ground. Even the increase in the numbers of illegal settlers in the second quarter of 2018 by comparison to the first quarter shows that Israel has adopted a holistic sovereignty approach over entire Palestinian territory (Israel illegal settlement construction more than doubled in 2018, 2018). According to international law, Israel's Basic Law should be evaluated in this context as an illegal attempt to justify its objective to be the sole sovereign in the entire Palestine territories.

This law serves to prove that international law will not be implemented objectively on an issue that directly affects Palestine. Palestinian demands of sovereignty should not be considered differently from the demands of sovereignty of any other states. However, in this case with Palestine, the situation is being processed entirely differently. Even though it is claimed by the Israeli side that the principle of self-determination is being adopted, the arguments that it should not be an absolute sovereign state by definition and it should be limited under the perception of Israeli security are being accepted (Davutoğlu 2003: 46). It is not possible to establish peace in an environment where the law is not being implemented objectively and the two sides have different levels of sovereignty. The recent efforts of Israel to expand its sovereignty through harsh means should be interpreted as an action that will eliminate any common ground to be found between the two sides for the peaceful resolution of the dispute.

\section{Conclusion}

The Israeli-Palestinian dispute continues to stand as one of the most longstanding conflicts that also transcend the regional borders. The disagreement has different sides, however in essence; it is a matter of struggle for sovereignty between the two sides. Israel, which gained the status of an exclusive Jewish nation-state and international support, is encouraged to put 
pressure on Palestine and enforce its absolute sovereignty, which only serves to destroy the possibility of establishing a common ground of mutual agreement. During the negotiations for establishing enduring peace between two sides, pro-Israeli attitudes resulted in the isolation of Palestine as the Palestinians have been denied of their sovereignty. Even though it did not implement any of the UN resolutions and violated international law several times, the State of Israel did not face any sanctions and benefited from this situation by expanding its demand of sovereignty over Palestine territories. As a result, the peace negotiations in the region are far from establishing peace and tranquillity for Palestinians (Aral 2016: 152). Far from achieving a permanent solution to the problem, during an important part of the negotiations, the right of sovereignty of Palestine is either ignored or diminished and the stalemate only deepened.

Especially with the new nation state law that was passed by the Israeli parliament, Israel has supposedly legitimized its de facto sovereignty and as a result, taken an important step in terms of denying the establishment of a Jerusalem-based State of Palestine. It could be seen that this expansionist policy - and the unconditional support and encouragement of the US to Israel - renders any attempts to hold peace talks meaningless. In this sense, the State of Israel clearly declares that it will not allow Jerusalem to become a topic of discussion or negotiation between the two sides. Considering the timing of the enactment, the basic law which refuses the sovereignty of Palestine - serves as a strategic tool to expand the area of manoeuvre for Israel. While the State of Israel continues to impose its absolute sovereignty over the former British Mandate of Palestine, the State of Palestine has been isolated. If the arguments of Israel and its newly-implemented basic law are legitimized in the eyes of international society, the Palestine case will inevitably become a tragedy.

In this context, the Palestine issue should be considered in light of the expansionist demands of Israel far beyond the attempts and arguments used to this day. To obtain a concrete resolution, the territories occupied by the State of Israel after the 1967 War should be disregarded by all sovereign states across the globe. Moreover, in order to convince Israel to retreat from these occupied Palestinian territories, all possible means including harsh economic sanctions and a multi-national military operation should be considered by the international society. In addition, in order to prevent the State of Israel from repressing the sovereignty of the Palestinian people, several initiatives are necessary: a fully independent and sovereign State of Palestine should be established, it should receive international support and protection from possible Israeli aggression, and the international society should ensure the recognition of the State of Palestine as Israel's equal rather than its subordinate in the global arena. Unless the full sovereignty of Palestine is established and the State of Israel is forced to adhere to the principles of international law, the Palestinian-Israeli conflict can never be peacefully resolved and the Middle East region can hardly hope to achieve political stability. If the international status quo - which protects and encourages the invasive character of Israel over Palestinian territories - is maintained in the foreseeable future, the Palestine issue will continue to remain an unsolvable stalemate for decades to come. 


\section{Notes}

1. The following news texts can be seen as examples of negative approaches to Hamas' legitimate victory (“CNN.com - Hamas' past casts shadow over peace plans - Jan 26, 2006”, n.d.; Erlanger 2006).

\section{References}

*'Israeli Authorities Approve 20,000 New Settlement Units in Jerusalem- IMEMC News' (2018, August 16). Retrieved 7 December 2018, from http://imemc.org/article/israeliauthorities-approve-20000-new-settlement-units-in-jerusalem/. İthaki).

Achcar, G. (2004) Kaynayan Orta Doğu: Marksist Aynada Orta Doğu (Istanbul:

Aral, B. (2016) Küresel Güvenlikten Küresel Tahakküme: BM Güvenlik Sistemi ve Íslam Dünyası (Istanbul: Küre Yayınları). 453-471.

Ball, G. W. (1977) 'How to Save Israel in Spite of Herself', Foreign Affairs 55 (3), pp.

Basic Law: Israel - The Nation State of the Jewish People. Retrieved from http://knesset.gov.il/laws/special/eng/BasicLawNationState.pdf.

Basic Law: Jerusalem the Capital of Israel, 5740 \& (1980). Retrieved from http://knesset.gov.il/laws/special/eng/BasicLawJerusalem.pdf.

Carr, E. H. (2001) The Twenty Years' Crisis, 1919-1939 (New York: Palgrave).

CNN.com - 'Hamas' past casts shadow over peace plans' - Jan 26, 2006. (n.d.). Retrieved $22 \quad$ May 2018, from http://edition.cnn.com/2006/WORLD/meast/01/26/palestinian.election/.

Davutoğlu, A. (2003) 'Küresel ve Bölgesel Dengeler, Ortadoğu Barış Süreci' in Filistin Çıkmazdan Çözüme (Istanbul: Küre Yayınları), pp. 3-47.

Declaration of Principles on Interim Self-Government Arrangements (Oslo Accords). (1993, October 11). United Nations General Assembly. Retrieved from https://peacemaker.un.org/sites/peacemaker.un.org/files/IL\%20PS_930913_DeclarationPrinci plesnterimSelf-Government\%280slo\%20Accords\%29.pdf.

Declaration on Principles of International Law concerning Friendly Relations and Cooperation among States in accordance with the Charter of the United Nations - UN Documents: Gathering a body of global agreements. (1970, October 24). Retrieved 5 September 2018, from http://www.un-documents.net/a25r2625.htm.

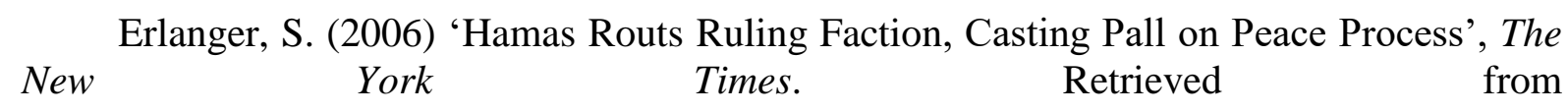


https://www.nytimes.com/2006/01/27/world/middleeast/hamas-routs-ruling-faction-castingpall-on-peace-process.html.

Hinsley, F. H. (1986) Sovereignty, $2^{\text {nd }}$ edition (Cambridge and New York: Cambridge University Press).

'Israel approves new W Bank settler homes' (2018, August 22). Retrieved from https://www.bbc.com/news/world-middle-east-45276555.

'Israel illegal settlement construction more than doubled in 2018' (2018, September 26). Retrieved 7 December 2018, from https://www.middleeastmonitor.com/20180926-israelillegal-settlement-construction-more-than-doubled-in-2018/.

Khalidi, R. (2006) The Iron Cage: The Story of the Palestinian Struggle for Statehood (Boston: Beacon Press).

Krasner, S. D. (1999) Sovereignty (Princeton: Princeton University Press).

Lake, D. A. (2003) 'The New Sovereignty in International Relations', International Studies Review 5 (3), pp. 303-323.

Lis, J. \& Landau, N. (2018, July 19) 'Israel Passes Controversial Jewish Nation-state Bill After Stormy Debate', Haaretz. Retrieved from https://www.haaretz.com/israelnews/israel-passes-controversial-nation-state-bill-1.6291048.

Morgenthau, H. J. (1993) Politics among Nations: The Struggle for Power and Peace (United States of America: McGraw-Hill).

Reus-Smit, C. (2014) 'International Law', in J. Baylis, S. Smith, \& P. Owens (eds.) The Globalization of World Politics: An Introduction to International Relations, $6^{\text {th }}$ edition (Oxford and New York: Oxford University Press), pp. 274-288.

Schmitt, C. (2010) Siyasi Illahiyat: Egemenlik Kuramı Üzerine Dört Bölüm (Ankara: Dost Kitabevi Yayınları).

Security Council Resolution of 242 (1967). Retrieved from http://www.un.org/Depts/dpi/palestine/ch3.pdf.

Security Council Resolution of 252, S/RES/252. (1968, May 21). Retrieved 5 September 2018, from https://unispal.un.org/DPA/DPR/unispal.nsf/0/46F2803D78A0488E852560C3006023A8.

Security Council Resolution of 478, S/RES/478 (1980). (1980, August 20). Retrieved 5 September 2018, from https://unispal.un.org/DPA/DPR/unispal.nsf/0/DDE590C6FF232007852560DF0065FDDB.

Staff, T. (n.d.) 'Netanyahu cheers Jewish state law as a 'pivotal moment' in Zionist history', Retrieved 7 December 2017, from https://www.timesofisrael.com/netanyahu-hailsjewish-state-law-as-a-pivotal-moment-in-zionist-history/. 
Thomson, J. E. (1995) 'State Sovereignty in International Relations: Bridging the Gap between Theory and Empirical Research', International Studies Quarterly 39 (2), pp. 213233. from

UN General Assembly Decision of 2253. (1967, July 4). Retrieved 5 September 2018, https://unispal.un.org/DPA/DPR/unispal.nsf/0/A39A906C89D3E98685256C29006D4014. from

United Nations (1997) The status of Jerusalem - Study (31 August 1997). Retrieved https://unispal.un.org/DPA/DPR/unispal.nsf/181c4bf00c44e5fd85256cef0073c426/533b4714 451b48bf0525651b00488d02?OpenDocument.

Waltz, K. N. (1979) Theory of International Politics (United States of America: McGraw-Hill).

Weber, M. (2008) Max Weber's Complete Writings on Academic and Political Vocations (New York: Algora Publishing).

Yurdusev, A. N. (2006) "'Uluslararası İlişkiler" Öncesi', in Devlet, Sistem ve Kimlik: Uluslararası İlişkilerde Temel Yaklaşımlar (Istanbul: İletişim), pp. 15-55.

Zacher, M. W. (1992) 'The Decaying Pillars of the Westphalian Temple: Implications for International Order and Governance', in J. N. Rosenau \& E.-O. Czempiel (eds.) Governance without Government: Order and Change in World Politics (Cambridge: Cambridge University Press), pp. 58-101.

\begin{abstract}
About the Author
Dr. Muhammed Hüseyin Mercan is Assistant Professor at the Department of International Relations at Ankara Yıldırım Beyazıt University, Turkey. He received his doctoral degree in Political Science and International Relations from Istanbul University. His research interests are Middle Eastern Politics, Syrian and Egyptian Political Systems and Foreign Policy, Turkish Foreign Policy and Islamic Movements. He is the author of Syria: Regime and Foreign Policy (in Turkish; Istanbul: 2012) and the editor of Transformation of the Muslim World in the 21st Century (Newcastle: 2016).
\end{abstract}

